УДК 336. 1:378. 1(477)

DOI: $10.31891 / 2307-5740-2020-288-6-14$

LAKTIONOVA O.

Vasyl's Stus Donetsk National University KOVAL V., SLOBODIANIUK O.

Odesa Institute of Trade and Economics of Kyiv National University of Trade and Economics

PRYSTUPA L.

Khmelnytskyi National University

\title{
FINANCIAL SUSTAINABILITY OF HIGHER EDUCATION INSTITUTIONS IN THE CONTEXT OF ENSURING THEIR DEVELOPMENT
}

The article presents a strategic approach to the formation of financial sustainability of higher education institutions (HEIs), aimed at its development. It is determined that financial sustainability in the context of the strategy of the development is provided by the current solvency, as well as the created financial space, which contains two interrelated components: current (operational) financial space as financial opportunities created by exceeding the university income (for functioning), as well as strategic financial space as financial opportunities created by exceeding the income of the university its necessary expanses for the development. The indicators of financial stability have presented, which are taken into account during the financial management and setting appropriate strategic objectives that allows to assess the gap between the declared goals of the development strategy and financial opportunities, to make decisions about the optimization of operating and investment activities of HEI.It is proposed that operating financial space is also evaluated on the basis of its characteristics, such as: diversification of funding sources and revenues, their stability and flexibility of use. To maintain the financial sustainability of the university, it is also important to increase the profitability of educational programs and educational activities. It is justified that profitability maintains the financial sustainability of the HEI, thatmakes the increasing the profitability of educational programs and educational activities an impotent issue of financial management. Margin of safety in the income of the special fund from the main activity relative to the break-even point by the number of students of the university (faculty) one of the crucial profitability indicator, that requires appropriate managerial accounting system.

Keywords: financial sustainability; tertiary education, development strategy, financial space.

ЛАКТІОНОВА О. А.

Донецький національний університет імені Василя Стуса

КОВАЛЬ В. В., СЛОБОДЯНЮК О. В.

Одеський торговельно-економічний інститут Київського національного торговельно-економічного університету

ПРИСТУПА Л. А.

Хмельницький національний університет

\section{ФІНАНСОВА СТІЙКІСТЬ ЗАКЛАДІВ ВИЩОЇ ОСВІТИ В КОНТЕКСТІ ЗАБЕЗПЕЧЕННЯ ЇХ РОЗВИТКУ}

\begin{abstract}
У статті представлено стратегічний підхід до формування фінансової стійкості закладу вищої освіти, націлений на його розвиток. Визначено, що фінансова стійкість в контексті стратегії розвитку ЗВО забезпечується поточною платоспроможністю, а також створеним фінансовим простором, що містить дві взаємопов'язані складові: поточний (операційний) фінансовий простір як фінансові можливості, утворені за рахунок перевищення доходів університету його мінімально необхідних витрат для виживання (функціонування), а такожстратегічний фінансовий простір як фінансові можливості, утворені за рахунок перевищення доходів університету його необхідних витрат для розвитку. Представлено індикатори фінансової стійкості, врахування яких під час управління фінансами ЗВО та встановлення відповідних стратегічних завдань дозволяєоцінити розрив між задекларованими цілями стратегіі розвитку та фінансовими можливостями, прийняти рішення щодо оптимізації операційної і інвестиційної діяльності.
\end{abstract}

Ключові слова: фінансова стійкість; вища освіта, стратегія розвитку, фінансовий простір.

Setting the problem and its relevance. In the context of the neo-industrialization of the world's economies, governments emphasize the growing importance of higher education and its use as a driver in achieving a number of national goals. Such goals include improving the skills of the population, increasing productivity and lifelong learning, increasing social integration, expanding inclusion, and implementing developments based on the knowledge economy. Specifically, the British government says that the main weapon of society in ensuring that we master change, not succumb to it, is the education system and mainly universities. In today's knowledge society Germany assigns the main role to higher education to identify political, social, economic, environmental and cultural needs and to address relevant issues [1].

In trying to catch up with the developed world in these processes, Ukraine in the field of higher education needs considerable efforts and adequate investments. According to the Strategy for the Development of Higher Education in Ukraine for the next 10 years, the mission assignby government is to ensure sustainable innovation development of Ukraine through training of highly qualified specialists, creation and dissemination of knowledge, formation of intellectual, social and spiritual capital of society[2]. However, in order to ensure that such lofty goals do not remain declarative, higher education management policies at both the macro and micro levels should be built 
on the experience of other countries in improving New public management practices, including financial management, to form more viable and financially stable systems that capable of fulfilling such an ambitious mission in the long run.

Analysis of recent research and publications. The issue of ensuring financial stability and financial management of HEIs is considered in many scientific investigationsduring the recent decades, in particularin the researches papers of Massy, W.F. [3], Swift, L.[4], Johnes, G., Johnes, J.[5], Alexander, K.F. [6], Modugno G. and Di Carlo F. [7], Sazonov S., Kharlamova, E., Chekhovskaya I., Polyanskaya E. [8], Kovalenko Yu. And Popovych L. [9]. At the same time, the issues of ensuring financial sustainability in the context of the implementation of HEI's development strategy, its components and indicators that correspond to a certain financial model of the HEItaking into account the specific public financing model and specific problems of certain countryremain relevant.

The aim of the researchis to identify the pillars and indicators most suitable for assessment of the financialsustainability in the context of development strategy realization on the level of HEI.

Results. Despite the different nature and extent of the problems that the world's higher education systems have accumulated over the past two decades, they have joincharacteristic- inevitability of the need to increase financial sustainability. Among such problems should be noted:expansion of the consumers base of educational services and their differentiation, which puts forward new requirements for reporting and criteria to quality; higher expectations of students regarding the quality of educational services due to the increase in their cost; reduction of public funding, in particular per student, due to the outstripping growth of their number in developed an some developing countries with increasing access to higher education; expanding the role of scientists, which requires universities to invest in advanced learning programs and development, increasesinvestments in scientific infrastructure; increasing sensitivity to the influence of market forces of supply and demand in the education market; rise of complexity of portfolio of goals and financing with increasing burden on income from other sources that are not stable in nature.

In contrast to most developed countries, where during the last several decades one of the directions of educational reforms was to increase access to education and growth of its inclusiveness, post-soviet countries, on the contrary, had significant problems with the reduction of the numberof enrollments as the result of demographic and economic problems. Over the last 10 years, the number of students inHEIs of 3 and 4 levels of accreditation (universities, institutes and academies) has decreased by $34 \%$ for students with public funding and by $44 \%$ with private funding (Fig. 1). Financing, on the other hand, lagged behind inflation in 2014-2017, distorting the already low financial potential of higher education.

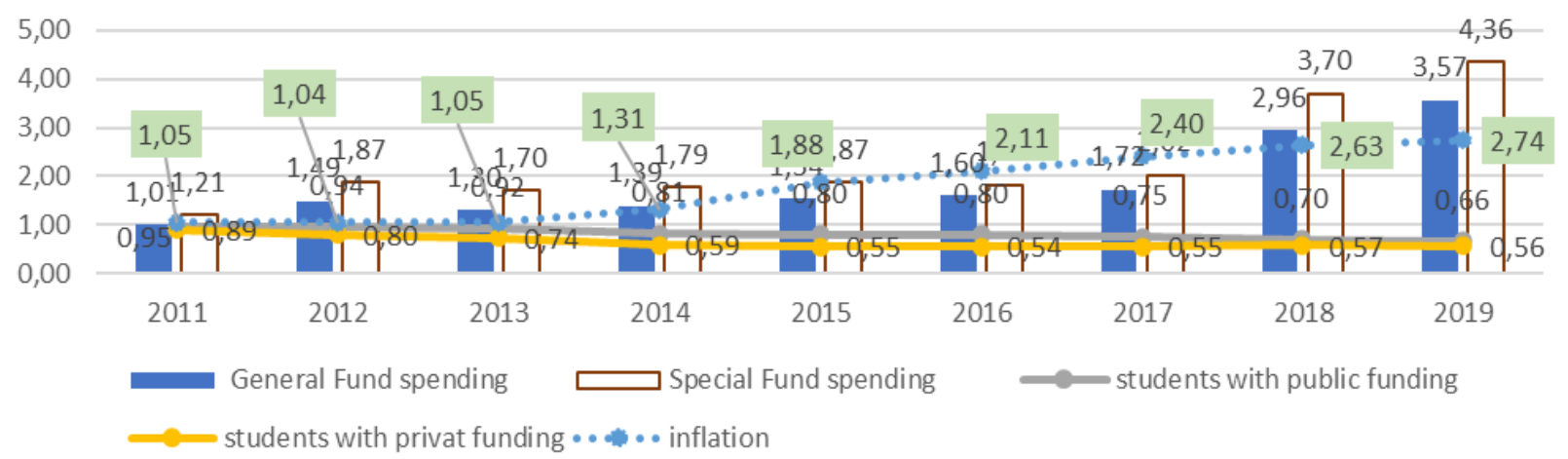

Fig. 1. Dynamics of financing of HEIs (universities, institutes and academies), the number of students and the level of inflation in Source: based on $[10]$ Ukraine comparing to 2010

Raising social standards with the minimum wage over the past three years, has stimulated a response with growth of public funding for higher education, but additional funds were directed only to the growth of the wage of staff without a chance to increase investment in development.

The share of investment in development in public financing of universities has decreased from $9 \%$ in 2000 to $3-4 \%$ over the past 8 years (Fig. 2). The share of funding for universities in total public expenditures also decreased to $2.9 \%$ in 2019 .

The decrease in the number of students accordingly affected the decline in their number per teacher (Fig. 3). This workload fell by $24 \%$ across the overall teaching staff and $22 \%$ among professors. It should be noted that without a corresponding improvement in quality high education in the long run in Ukrainian universities, this situation will reduce the financial efficiency and financial stability of HEIs, respectively.

Without obvious success in the quality of higher education, the devaluation of its image and values in society, education remained an "expensive" item of expenditure for the public budget compared to the cost for those who studied at their own cost (Fig. 4). On average, the cost of studying a student with public finance was twice as 
expensive as theprice of private financing student, although the cost of such education for the university was essentially the same.

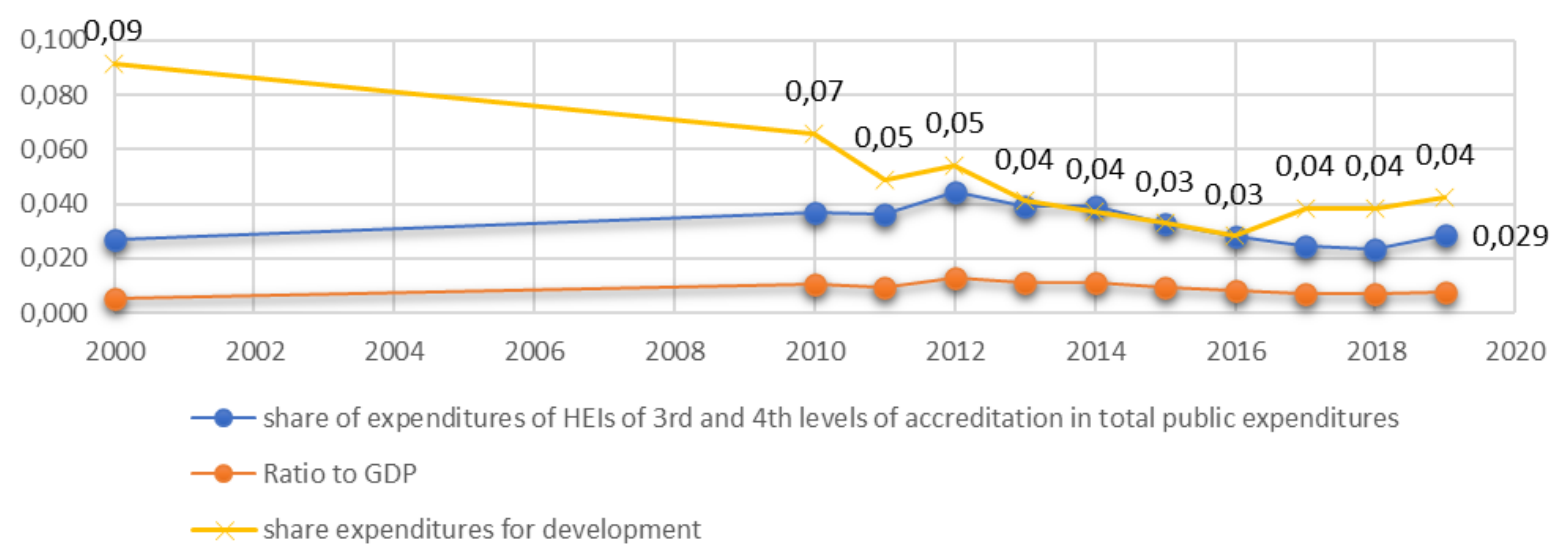

Fig. 2. The share of university expenditures and development expenditures in public expenditures and their ratio to GDP Source: based on [10]

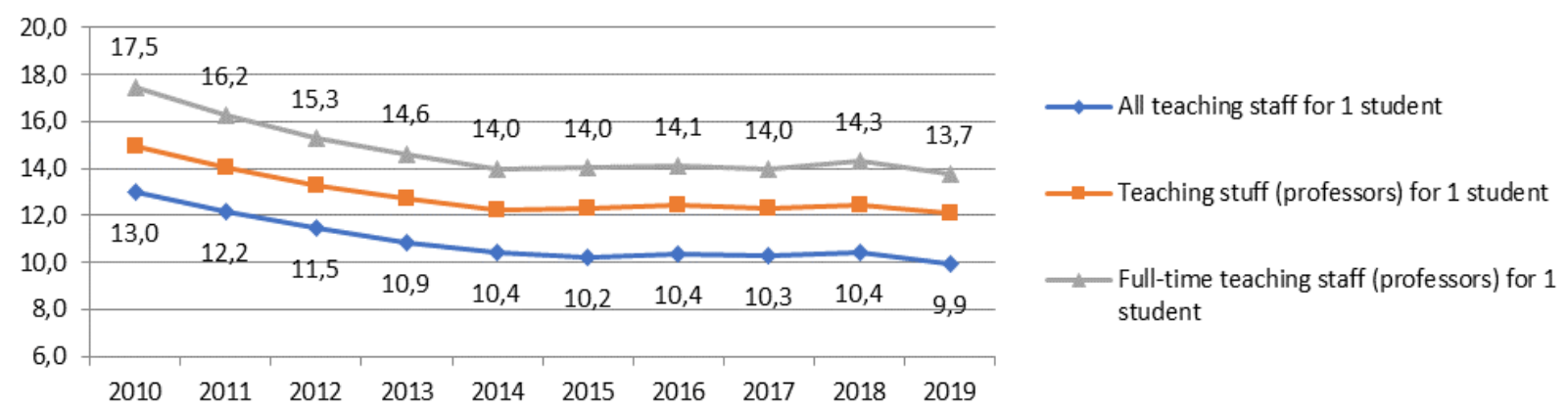

Fig. 3.The number of students per one person of teaching staff

Source: based on [10]

In the context of reduced budget funding and insufficient or no funds for development, universities around the world are increasingly using business approaches to improve the efficiency of financial management. However, it should be noted that HEIs have a number of differences:HEI is guided by an academic vision that is not directly related to financial goals;HEI has the essence of public service and social responsibility, which forces it to provide services that cannot be considered financially profitable in business;academic staff has a certain degree of independence in the direction and direction of their work (especially research);HEI often lack the ability to manage their costs and performance as much as is normal for business;management and governance often depend on dedicated people rather than professional managers. Senior positions may be held by faculty members appointed by their peers, often on a part-time or rotating basis.

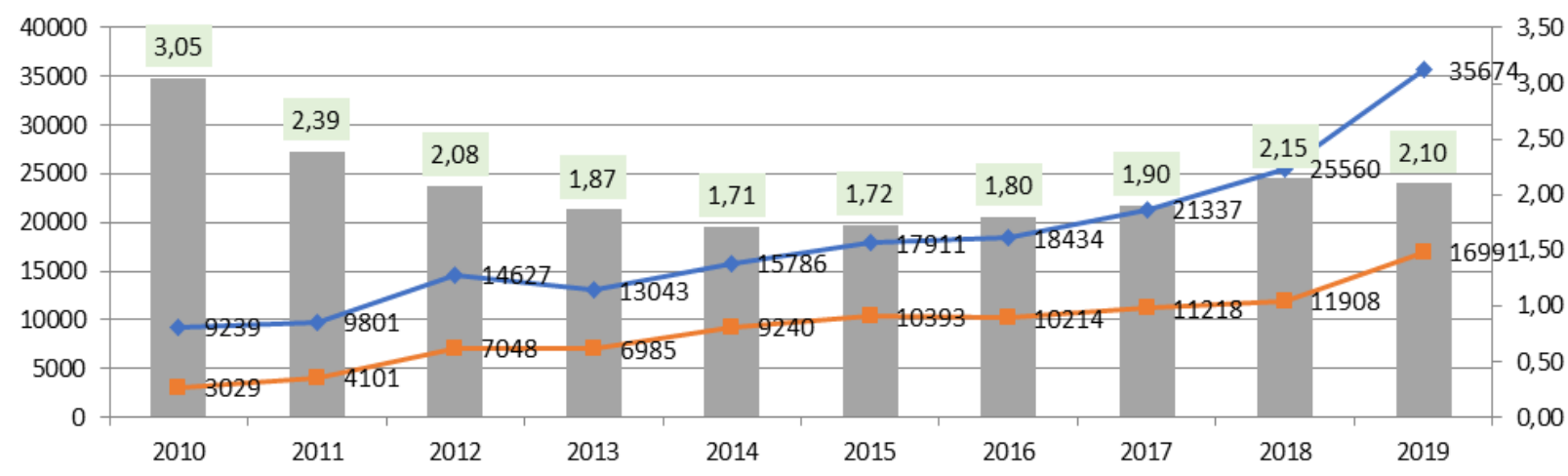

ratio of public financing by compared to private financing for one student

$\longrightarrow$ Public finance for one student

- - Private finance for one student

Source: based on [10-11]

Fig. 4. The cost of private and public financing per one student in Ukraine 
It should be noted, that good financial management in the traditional sense of the public sector, although necessary, is insufficient to address such issues. This will not protect HEI from bad strategies, from market risks or from insufficient funding (or from its own unrealistic plans). Nor will it help to position themselves adequately to deal with the much wider range of commercial and other opportunities they now have.HEI also need to apply some methods of strategic financial management, which are more common for business.

Financial sustainability is defined as the ability to cover annual budgets without restrictions. This indicates that the income or revenue generated by the organization exceeds operational expenses [12].

There is a subtle difference between financial sustainable and financial self-sufficiency [13]. Financial stability means ensuring the longevity of the organization. On the other hand, financial self-sufficiency involves the management of the organization without recourse to external financial assistance. Self-sufficiency can also be interpreted as the ability of an organization to fully cover its costs. A sustainable firm is able to survive in the long run thanks to its own means of earning its own income.

Thus, financial sustainability aims to ensure that HEI can receive adequate income so that it can effectively carry out its activities and invest in its academic and research activities without relying too heavily on external sources of funding, such as government. It is stated that HEI, such as universities, should consider three key pillars to ensure financial sustainability, which identifies and better understands the costs of all activities and projects, maintains a reasonably diversified revenue structure and, moreover, sufficient, reliable sustainable public funding. adequate accountability measures [14].

Financial sustainability as well can be defined as follows - an institution is managed on a financially sustainable basis if it reimburses all its economic costs and invests in its infrastructure (physical, human and intellectual) at a rate sufficient to maintain the future production capacity needed to implement its strategic plan and serve its students and other clients. This definition provides four key elements of sustainability management:

- strategy - HEI has clear guidance and tools to assess its future needs and risks and to measure its performance.

- efficient work - HEI reimburses costs and receives income to cover its expenses for its normal work.

- investmentthat at the appropriate level to maintain output capacity.

- risk management - it performs proper risk management in accordance with its strategy and is ready to address potential financial problems.

Functional strategy of financial activity of HEI- a set of methods and tools for financial management, types and forms of financial relations, providing financial opportunities for the implementation of the development strategy of university named and designed to:

- provide the mechanism of realization of long-term main purposes of activity of university and its structural divisions;

- use the methodology of strategic management with its clear interrelation with the current and operational management of financial activities;

- take into account the need to strengthen orientation of university and its structural units on the key result with the use of appropriate leverages of influence;

- be based on a realistic assessment of the financial capabilities of the university and ensure maximum use of internal financial potential and the ability to actively maneuver financial resources;

- take into account possible changes in environmental factors and respond in advance to legislative changes in the mechanisms of financing higher education institutions, strengthening their financial autonomy;

- form a system of criteria for evaluating the choice of the most important financial decisions and their values;

- creating opportunities for strategic changes in the organizational structure of management and organizational culture of the university.

Financial strategy should use such tools as:

- themodel of formation and tools of distribution and redistribution of financial resources on the level of university;

- levers of stimulation of all types of activity of divisions of university and personnel development of stuff;

- basic model for calculating and estimating the full cost (cost) of educational services;

- financial planning and budgeting;

- formation of the mechanism of interaction of financial and managerial accounting, rating system of estimation and other key performance indicators of activity of structural divisions;

- monitoring, analysis and control over the achievement of financial results, economic efficiency of management decisions;

- review of organizational structures and responsibilities.

Financial sustainability is one of the most important characteristics for assessing the financial performance at university. Only those universities that have sound financial performance and stable income flows will be able to fulfill their mission and respond to current challenges in an increasingly complex and global environment [15].

The basis of financial sustainability in strategic management is the maintenance of current solvency, as well as the creation of an appropriate financial space, which can be represented by two interrelated components: 
- current (operational) financial space - is the financial opportunities created by exceeding the income of the university of its minimum necessary expenses for survival (operation activity);

- strategicfinancial space - is the financial opportunities created by exceeding the income of the university its necessary expenses for development. financial space.

Accordingly, the gap in the financial space is the value of the negative current (operational) or strategic

The indicators of the current solvency of the university, from our point of view, include: ensuring the stability of the balance of funds on the current account (monthly; daily); reduction of receivables for tuition up to $5 \%$ of accrued income for the relevant period; ensuring a stable positive net cash flow from operating activities from budget revenues; ensuring a stable positive net cash flow from operating activities on extra-budgetary revenues and increasing passive income from managing the free balance on the account.

Among the strategic measures to increase the current solvency of the university are: passive income.

1. The improvement of the efficiency of free cash flow management based on the principles of liquidity and

2. The improvement of the system of long-term, medium-term and short-term financial planning and budgeting (budget of revenues and expenditures by main items, cash flow budget, material expenditure plan).

3. The increase of payment discipline by the recipients of educational services.

To determine the current (operational) financial space, it is necessary to determine the minimum necessary expanses for operation activity (for implementation of survival strategy):

Minimum required costs for operation activity (implementation of survival strategy) $=$ Remuneration of faculty (staff) + Remuneration of support and administrative staff + Fixed costs

In turn, to determine the strategic financial space and, accordingly, its coverage, the required minimum expenses are calculated:

Necessary expenses for the implementation of the development strategy $=[$ Remuneration of faculty (staff) + Remuneration of support and administrative staff + Fixed costs $]+$ Remuneration of faculty (external part-time) + Investment in development.

Operating financial space is also assessed on the basis of its characteristics, such as: diversification of funding sources and revenues, their stability and flexibility of use. Thus, the level of income diversification of the university is estimated: services;

- by types of activity: from the main (academic); scientific; from the provision of other educational

- according to the structure of the main (academic) activity - the share of income from bachelor's and master's programs, part-time and full-time forms of education;

- by sources of funding: from the public budget; extra-budgetary funds (tuitions and payments for other services; grants; charitable contributions and gifts).

Suitability of income from relevant sources and from relevant activities is assessed on the basis of the share of sustainable sources (from the main activity - a bachelor's degree 4 years, master's degree - 1.5 years, contract) - a share of the total. The share of flexible sources of funding is the share of sources with the ability to choose areas of funding or without a defined target structure by the state.

To maintain the financial sustainability of the university, it is also important to increase the profitability of educational programs and educational activities. Profitability indicators could be such as:

- income of the university (faculty) per 1 tuition-paying student;

- increased income of the university (faculty) from the main activity by 1 person of teaching staff;

- income of the university from the main activity at 1 person of additional staff (non-teaching staff);

- the share of income from "effective", "budget-generating" educational programs in the total income from the main activities of the university (faculty);

- margin of safety in the income of the special fund from the main activity relative to the break-even point by the number of students of the university (faculty). In this case, the margin of safety in the income of the special fund from the main activity relative to the break-even point for the number of students of the university (faculty) is equal to the difference between the actual number of tuition-payingstudents and break-even point. Break-even point in the number of tuition-paying students is calculated:

$$
\text { Break-even point }=\frac{\text { Fixedcostsof theuniversity }(\text { coveredbyaspecialfund })}{(\text { Weighted average price for } 1 \text { student-Direct costs for } 1 \text { student })} .
$$

Thus, marginal income is equal to the difference between income and variable costs per student. Variable (conditionally variable) costs are the costs that depend on the number of students. Preferably, these include the cost of on teaching stuff. 
Coverage of certain expenses of the university by income from the relevant activities is also an important sign of its financial sustainability. Thus, the key is the degree of coverage of labor costs on teaching staff (direct) and part of the permanent (for the payment of support staff, rent, and utilities) sources of income from the main activity in terms of faculties and the university as a whole.

Financial stability cannot be achieved without increasing the optimality of the cost structure, namely, reducing the share of fixed costs in the structure of total costs

As mentioned above, the strategic financial space is the financial opportunities created by exceeding the income of the university its necessary expenses for development. In this case, the necessary expenses for the implementation of development strategy include investment in development - the cost of training teaching staff and personnel, the cost of purchasing fixed assets, laboratory equipment, and library, publishing educational and scientific literature, software. Increasing the size (elimination of the gap) of the strategic financial space in the planning period is an important task of the university strategy.

Conclusions. Ensuring strategic financial stability should also be based on the growth of financial opportunities (financial space) for professional growth, the formation of decent working conditions for teaching staff and the recovery of human resources; growth of the average salary per one teacher (by university / faculties); reduction of classroom load per teacher (at the university, by faculties); increase in the amount of allowances, bonuses and incentives per staff member; increase in financing of expenses for advanced training of professors, administrative staff per one person (by university / faculties); increase investments in acquisition of fixed assets, laboratory equipment, library fund; publication of educational and scientific literature; purchase of software and bringing them to the amount of not less than $10 \%$ of the special fund for the main activity; financial support for the fulfillment of licensing requirements for logistics, including multimedia equipment for simultaneous use in classrooms (not less than 25\%).

All of the above allow building a model for the analysis of HEI's financial sustainability thatidentifies financial spaces for operating and investment activities or their gaps. This is acritical issue for most public organizations and HEI in particular: financial weaknesses would undermine other facets ofsustainability, i.e., social and organizational sustainability. The model for the analysis is based onspecific financial ratios, whose aim is to analyze the organization's current situation and not also topredict future conditions of financial sustainability.Financial sustainability provide the opportunities of realization of long-term main purposes of activity of HEI and its structural divisions.

\section{References}

1. OECD (2019). On the Edge: Securing a Sustainable Future for Higher Education. Retrieved fromhttps://www.oecdilibrary.org/education/on-the-edge_220180871707

2. Reform(2020). StrategyforthedevelopmentofhighereducationinUkrainefor 2021-2031. Retrieved fromhttp://www.reform.org.ua/proj_edu_strategy_2021-2031.pdf

3. Massy W.F. (2007). Cost and pricing in higher education. In E. Fiske, \& H. Ladd (Eds.).Handbook of Research in Educational Finance and Policy. London: Taylor \& Francis.

4. Swift L. (2010). Evaluation of the sustainability of postgraduate programs in the faculty of the professions at the University of Adelaide. Paper prepared for the MTEM, L.H. Martin Institute, University of Melbourne,November.

5. JohnesG.,\&Johnes J. (2009). Higher education institutions' costs and efficiency:Taking the decomposition a further step. Economics of Education Review,28, 107-113.

6. Alexander K.F. (2000). The changing face of accountability: Monitoring andassessing institutional performance in higher education. Journal of HigherEducation, 71(4), 157-165.

7. Modugno G., Di Carlo, F. (2019). Financial Sustainability of Higher Education Institutions: A Challenge for theAccounting System. In Financial Sustainability of Public Sector Entities; Palgrave Macmillan: Cham, Switzerland.

8. Sazonov, S.P.,Kharlamova, E.E.,Chekhovskaya, I.A.,Polyanskaya, E. (2015). Evaluating Financial Sustainability ofHigher Education Institutions. Asian Soc. Sci., 11, 34-40.

9. Kovalenko Yu., Popovych L. (2018). Financing of higher education institutions: problems and directions of improvement in Ukraine.Problems and prospects of economy and management, 1 (13), 150-159.

10. Treasury(2020). ReportsontheexecutionoftheStateBudgetofUkraine. Retrieved from //www.treasury.gov.ua/ua/file-storage

11. StateStatisticsServiceofUkraine (2020).Retrieved from http://www.ukrstat.gov.ua/

12. Pollinger, J.J., Outhwaite, J., \& Cordero Guzman, H. (2007). The question of sustainability for microfinance institutions. Journal of Small Business Management,45(1), 23-41.

13. León, P. (2001). Four pillars of financial sustainability. Arlington, Va: Nature Conservancy.

14. Estermann T.,Pruvot, E.B. (2011).Financially sustainable universities: European universities diversifying income streams. European University Association, Brussels, Belgium.

15. Kvitka, S., Starushenko, G., Koval, V., Deforzh, H., \& Prokopenko, O. (2019). Marketing of Ukrainian higher educational institutions representation based on modeling of Webometrics Ranking. Marketing and Management of Innovations, 3, 60-72. http://doi.org/10.21272/mmi.2019.3-05 